\title{
Na Festa, no Escritório, na Cabine do Trator: notas sobre o comércio de insumos agrícolas no "agronegócio” da soja
}

Luciana S. Almeida'

\section{Resumo}

A dimensão comercial da produção agrícola mobiliza, de modo expressivo, os produtores de soja da região central do Mato Grosso, precisamente da microrregião do Alto Teles Pires. Seus relatos revelam que a comercialização do produto, desde a implantação das lavouras no final dos anos 1970 até os anos 1990, ocorria sem a necessidade de cálculos aritméticos precisos para a obtenção de bons resultados comerciais. A tendência à diminuição da margem de lucro e a sofisticação das técnicas produtivas hoje demandam dos produtores a realização de cálculos complexos e minuciosos. Este artigo procura explorar uma pequena parte desse universo dos negócios agrícolas enfocando transações comerciais entre vendedores de insumos agrícolas e produtores de soja. A proposta é mostrar como os complexos cálculos do mercado de commodities agrícolas envolvem aspectos que extrapolam o "econômico", como as reputações das partes. Veremos que essas trocas podem ser entendidas explorando as pontes entre racionalidade "econômica" e moralidades.

Palauras-chave: Agronegócio. Mercado. Moralidades.

\section{Introdução}

No Alto Teles Pires, onde o cultivo de soja é hegemônico, seus ciclos agrícolas e os resultados das safras exercem imensa influência no cotidiano dos municípios. A preparação dos solos, do plantio até a colheita, movimenta a rotina das fazendas que, no período de entressafra da soja, experimentam relativa calmaria - ainda que nesse período tenham sido cultivados outros produtos como o milho "safrinha". O desenvolvimento da planta ocorre ao longo do verão chuvoso. Depois do alvoroço característico da colheita, inicia um período de seis meses de um clima seco e quente que coincide com a intensificação do calendário festivo que mobiliza os produtores e suas famílias.

I Doutora em Antropologia pelo IFCS/UFRJ. Professora adjunta da Universidade da Integração Internacional da Lusofonia Afro-brasileira (UNILAB). Endereço para correspondência: Av. Juvenal Eugênio Queiroz, s/n-Centro, CEP: 43.900-São Francisco do Conde/BA. E-mail: luciana.almeida@unilab.edu,br. 
As maiores festas promovidas nos municípios da região são as "exposições" ou feiras agropecuárias que muitas vezes marcam o aniversário de emancipação da cidade. A festa é muito aguardada pela população, havendo grande expectativa em relaçáo às atraçôes musicais, considerando que são ocasióes em que as cidades recebem artistas de renome nacional. As datas das festas dos municípios vizinhos náo coincidem, de modo a permitir que o público circule. Há, inclusive, certa rivalidade entre as cidades pela exposição mais grandiosa.

Essas festas duram pouco menos de uma semana. Os terrenos reservados para as exposições são organizados em setores de estandes de fábricas e comércios locais de artigos diversos desde piscinas até roupas, artigos para animais de estimação, erva-mate, móveis, eletroeletrônicos, motocicletas, máquinas agrícolas. Ademais, são instalados restaurantes e parque de diversóes com as barraquinhas de lanches e bebidas. Ao longo da festa, além dos shows, são promovidos bailes à noite. É comum, também, que haja exposição de animais (equinos, bovinos e ovinos).

Frequentando essas exposiçóes, náo resta dúvida de que o setor de máquinas agrícolas é o mais prestigiado. As revendas instaladas no município levam para o parque de exposiçóes seus últimos lançamentos. Pulverizadores e colheitadeiras, toda sorte de tratores e equipamentos ficam dispostos, devidamente limpos e reluzentes, exercendo forte apelo sobre o público. Famílias, casais, grupos de adolescentes passam observando sem pressa. Os homens e as crianças demonstram mais entusiasmo pelas máquinas, que também são panos de fundo preferidos para as fotos

Além das máquinas, esses estandes contratam músicos para animar o ambiente e existe o costume de promover churrascos reunindo seus clientes. Nessas ocasióes, os produtores - ou "agricultores" como eles preferem se identificar - comparecem com esposa, filhos e demais familiares. Acompanhei uma família de produtores em um desses eventos, promovido pela revenda New Holland, ocasiáo em que havia pouco mais de uma centena de pessoas. As máquinas em exposição foram deslocadas para as bordas do estande e, no centro, foram dispostas mesas para refeição.

$\mathrm{O}$ ponto alto do encontro foi o momento em que, enquanto os convidados serviam seus pratos, uma máquina gigantesca e uma plataforma 
colheitadeira estacionaram triunfalmente em frente às mesas. Aos poucos, as pessoas levantavam das cadeiras e se aproximavam, para apreciar a máquina. Tratava-se da colheitadeira considerada, na época, a mais moderna e cara do mercado, sendo a única em operação no Mato Grosso - pertencente a um eminente produtor local.

Esse esforço de aproximação com os clientes em situações lúdicas não se restringe ao período das grandes exposições. Os dados obtidos em campo permitem afirmar que a efetivação de uma venda é resultado de uma longa negociação envolvendo não somente cálculos aritméticos como também o estabelecimento de uma relação de confiança. Diversas situações de encontro na cidade e na zona das fazendas devem confluir para criar um clima de "amizade" ou certa "intimidade" imprescindível para fazer negócios. A importância dessa forma de vínculo está relacionada com a relevância de garantias pessoais para o bom andamento dessas transações.

Esse artigo visa a explorar alguns aspectos da relação entre vendedores de insumos agrícolas e produtores da região de modo a explicitar como essas trocas não são definidas somente em função dos preços e das condições dos contratos. Veremos que, na produção e comercialização de commodities agrícolas como soja e milho, as reputações ${ }^{2}$ das partes envolvidas são fatores fundamentais na estruturação desses mercados.

Entre fevereiro e junho de 2008 e em rápida estada de duas semanas em setembro de 2010, estive na região realizando incursões etnográficas e procurei estabelecer contato com famílias de produtores e de comerciantes engajados na sojicultura, buscando acompanhar seu cotidiano e as festividades que

20 conceito de "reputação" que fundamenta essa análise foi formulado por BAILEY (197I), autor que defende que ter boa reputação significa dominar as regras do jogo social e ter as condições de disputá-lo para vencer, o que pode ser verificado através da capacidade de atores sociais em influenciarem pessoas e fazer amigos. "A man's reputation is not a quality that he possesses, but rather the opinions which other people have about him. It matters who these other people are. My reputation is one of the factors which control the ways I can interact with other people and manipulate them to gain whatever ends I have in view. Therefore only the opinions of those with whom I am likely to interact are importante to me. If people on the other side of the world learn from a news-paper what a fine fellow I am (or what a cad), this is of no concern unless I come into contact with those people. The importance of one's reputation diminishes as the intensity of interaction also diminishes. Only in front of those with whom I interact frequently must I take care to manage the impression which they gain of me." (BAILEY, I97I, p. 4). 
os mobilizavam. O objetivo da pesquisa era entender a visão de mundo dessas novas elites agrárias, formadas no processo de avanço da grande agricultura sobre Cerrado e Amazônia, sobretudo a partir dos anos 1970.

As informações obtidas dizem respeito à cerca de 30 famílias de produtores, dos municípios de Lucas do Rio Verde e de Sorriso, ambos localizados no traçado da BR 163 (Cuiabá-Santarém). ${ }^{3}$ Conforme a escala nativa, em sua maior parte, os produtores contatados eram considerados "médios" que plantavam entre 1.000 e 5.000 hectares; cinco eram considerados "grandes" por plantar cerca de 10.000 hectares. Com cinco dessas famílias, mantive contato constante ao longo do trabalho de campo - sendo uma delas considerada de "pequenos" produtores por plantar 600 hectares de soja, reunindo terras próprias e arrendadas. ${ }^{4}$ Também foram realizadas entrevistas com vendedores de insumos agrícolas, sendo quatro vendedores de máquinas agrícolas, três, de sementes, fertilizantes e pesticidas, além de um fornecedor de serviços de armazenagem.

\section{O Mato Grosso como "área nova”}

A soja está presente em diferentes regióes do Mato Grosso, sobretudo no sudeste (regiáo de Rondonópolis e Primavera do Oeste) e no Meio-norte (que inclui a microrregiáo do Alto Teles Pires), além das áreas de expansão na Chapada dos Parecis a oeste e no vale do Rio Xingu.

Nos anos 1970, essas lavouras, que estavam concentradas na parte meridional do país, foram expandindo na direção do Cerrado, da Amazônia e do Oeste Baiano (HEREDIA; PALMEIRA; LEITE, 2010). Nas planuras do Mato Grosso, esses cultivos foram especialmente prósperos, consolidando o estado como maior produtor de soja no Brasil. ${ }^{5}$

3 Esse texto tem como base minha pesquisa de doutorado, realizada no Meio-norte matogrossense. (ALMEIDA, 2013) O objetivo do estudo foi entender o modo de vida das famílias daqueles que administravam a produção tendo como ponto de partida suas formas de sociabilidade. Essa pesquisa integrou o projeto de pesquisa "Sociedade e Economia do Agronegócio: um estudo exploratório" coordenado por Beatriz Heredia (PPGSAUFRJ) - que orientou a tese -, Moacir Palmeira (PPCAS-UFRJ) e Sergio Pereira Leite (CPDA - UFRRJ) e Leonilde Medeiros (CPDA - UFRRJ). Projeto financiado pela Fundação Ford e CNPq.

4 É importante notar que há produtores que cultivam áreas menores que 600 hectares, inclusive em assentamentos existentes nos municipios visitados, mas que não estão incluidos no universo das famílias pesquisadas. Sobre essa parcela dos produtores, ver: DESCONSI (20II), que pesquisou na mesma microrregião do Alto Teles Pires, e WESZ JUNIOR (20 I4), que realizou pesquisa no Sudoeste do Mato Grosso.

5 Sobre a expansão da soja sobre o Mato Grosso ver FERNANDEZ (2007) e WESZ JUNIOR(2011). 
O estabelecimento das lavouras mecanizadas e de novos núcleos urbanos ocorreu através do que pode ser chamado de um programa oficial de colonizaçáo implementado durante os governos militares. Tal empreendimento fazia parte de um programa de desenvolvimento agrícola cujas premissas consistiam na liberação de mão de obra para o setor industrial (sem diminuir a quantidade produzida de alimentos); na criação de mercados para produtos da indústria e na expansão das exportaçóes e financiamento de parte da capitalização da economia. A consolidaçáo de uma agricultura eficiente conforme esses princípios liberais, marcada pela mecanização, ocorreu sem ameaçar a concentraçáo fundiária, redundando em um processo que estudos definem como "modernização conservadora" (DELGADO, 2001; SORJ, 1998). A ocupação dessas "novas áreas" no Mato Grosso foi possível graças ao empenho estatal em construir estradas que dessem acesso a regióes relativamente isoladas e em proporcionar condiçóes para alavancar o mercado de terras. As empresas colonizadoras entraram em cena loteando imensas glebas e prosseguindo na construção de infraestrutura mínima para favorecer a fixação de população ${ }^{6}$ Esses empreendimentos tinham como público-alvo pequenos agricultores oriundos de "áreas coloniais" no Sul do Brasil", de modo que a população preestabelecida foi incluída de forma marginal ou arbitrariamente expulsa da região.

Conforme Tavares dos Santos (1993), a opção pelos "colonos" tinha como justificativa os seguintes fatores: a) tratava-se de uma classe de produtores agrícolas já familiarizados com a mecanizaçáo, b) muitos foram impelidos de suas regióes de origem em funçáo de tensóes sociais criadas pela escassez de terras, c) as famílias oriundas dessas regiōes já haviam sido bem-sucedidas em projetos de colonização nos anos 1950/1960 em Santa Catarina e no Paraná. A preferência por tais colonos tinha a ver com a crença de que se tratava dos

6 Entre os produtores que participaram das primeiras levas de colonos é comum ouvir que o sucesso da empreitada pioneira, assim como a formidável produção agrícola atual, são conquistas atribuídas ao empenho pessoal. Nessa narrativa, o Estado tende a ser visto mais como uma espécie de obstáculo em sua burocracia ineficiente. Os estudos sobre esse processo de transformação indicam, no entanto, o papel decisivo das políticas governamentais na regulação da economia, no ordenamento territorial, trabalhista, ambiental, de crédito, de infraestrutura. Sobre a política fundiária na ocupação do Mato Grosso, ver MORENO (2007); sobre as políticas de crédito agricola, ver LEITE e WESZ JUNIOR (2014).

7 As "áreas coloniais" são resultado da política de colonização do século XIX que atraiu colonos europeus $e$ que tinha por objetivo o povoamento e o estabelecimento de pequenos agricultores que desenvolvessem a produção de alimentos básicos. Nas "áreas coloniais", adquiriram lotes de terra de 20 a 50 hectares para cultivá-los em um regime de policultura e trabalho familiar (SEYFERTH, 1990). 
tipos sociais mais aptos a empreender a expansão da "agricultura moderna". Nessas "áreas coloniais", corriam notícias sobre as terras baratas e planas, favoráveis à mecanização, através da imprensa local e do boca a boca. Circulavam corretores de terra aliciando compradores, promovendo reunióes e caravanas para - conhecer o Mato Grosso.

Esse processo de ocupação, portanto, esteve baseado, entre outros aspectos, na atração de migrantes das “áreas coloniais", notadamente descendentes de alemáes e italianos que desembarcaram no país ao longo do século XIX. O deslocamento dessas famílias foi assegurado por crédito abundante e facilidades burocráticas que deveriam compensar as condiçóes precárias nos primeiros anos desses projetos, uma vez que os colonos confrontariam áreas ainda selvagens. Boa parte desses colonos consolidaram-se como produtores de commodities agrícolas, especialmente soja.

Nem todos os colonos suportaram os desafios impostos por essa empreitada pioneira, mas muitos ficaram e lograram consolidar as novas cidades e lavouras. O deslocamento para o Mato Grosso significou, também, uma mudança de status. Nas "colônias", as famílias viviam em lotes que raramente ultrapassavam os 50 hectares, terra voltada para a policultura, trabalhada com a mão de obra familiar e técnicas tradicionais. No Mato Grosso, tornaram-se proprietários de extensas fazendas monocultoras voltadas, sobretudo para a exportação. Os "colonos" egressos das "colônias" no do Rio Grande do Sul, de Santa Catarina e do Paraná, na nova área, passaram a ser chamados "gaúchos".

\section{Negócios nas festas, festas nos negócios}

O mercado da soja no Mato Grosso é marcado pela elevada internacionalização nessa cadeia produtiva e por um movimento de "verticalização da produção" ou da apropriação das diferentes etapas dessa cadeia por uma mesma empresa. "Nas empresas a montante e a jusante, uma característica comum é concentração de firmas multinacionais, que estão presentes em diferentes países e que transacionam entre si distintas mercadorias, ligando a soja mato-grossense às cadeias globais.” (WESZ JUNIOR, 2014, p. 135).

As informaçóes reunidas em campo dizem respeito a esse segmento, à montante da cadeia produtiva, especialmente a comercializaçáo através de revendas de máquinas e equipamentos; sementes, fertilizantes e 
defensivos (herbicidas, fungicidas, acaricidas e inseticidas). Conforme Wesz Junior (ibid.), existe a possibilidade de comprar direto na indústria ou coletivamente através da organização em cooperativas, no entanto, as tratativas com as revendas ${ }^{8}$ são mais comuns:

O mais usual, principalmente para os médios e pequenos produtores que não estão organizados em cooperativas, é a compra nas revendas, onde são contratados os chamados "pacotes", em que são vendidos sementes, fertilizantes e defensivos de forma agrupada ("venda casada"), além da assistência técnica oferecida ao longo da safra (na maioria dos casos o valor da ATER é estabelecido a partir de um percentual da safra colhida). O pagamento do "pacote" pode ser à vista (prazo curto) ou na safra, em dinheiro ou em soja (geralmente o valor é convertido em sacas de soja e é quitado com o grão). Para aqueles que pagam após a colheita, é recorrente a realização de um contrato com CPR ${ }^{9}$ (WESZ JUNIOR, 2014, p. 122).

Ao percorrer municípios como Sorriso e Lucas do Rio Verde, localizados às margens da BR 163, é possível notar sua configuração espacial semelhante, formado por um núcleo urbano central, circundado por lavouras..$^{10}$ À beira da rodovia, no trecho que corta seus perímetros urbanos, é possível observar uma concentração de armazéns e silos, revendas de máquinas agrícolas, de sementes, fertilizantes e pesticidas (em Sorriso, onde havia cerca de $600 \mathrm{mil}$ hectares de soja, funcionavam aproximadamente 30 revendas conforme os informantes). Nas ruas centrais da cidade, também encontramos inúmeros estabelecimentos comerciais voltados para a agropecuária. Esses traços permitem entrever que é na cidade que os produtores conseguem acessar equipamentos e serviços técnicos essenciais para a produção nas fazendas; sem falar em

8 A comercialização por intermédio de revendas vincula aquisição de produtos e assistência técnica. Conforme WESZ JUNIOR (2014), trata-se de um modelo que acabou absorvendo muitas "agropecuárias" ou estabelecimentos comerciais que vendiam produtos de distintas marcas e não tinham como estratégia a oferta de serviços, além de comercializar também produtos para pecuária.

9 "A Cédula de Produto Rural (CPR) é um tipo de contrato a termo, em que o produtor recebe antecipadamente um montante em dinheiro/produto correspondente à quantidade de produto comprometida para entrega futura. Ou seja, o produtor vende a termo sua produção, recebendo o valor da venda à vista, comprometendose a entregar o produto negociado na quantidade, qualidade, data e local estipulado. Por se tratar de um contrato a termo, destaca-se que a CPR também funciona como um instrumento de proteção de preços para o produtor." (WESZ, 2014, p. 122)

10 Embora o cultivo de soja seja predominante, essas zonas rurais apresentam alguma diversidade: existem criações de gado bovino e suíno, além de pequenas propriedades, chamadas "chácaras", voltadas para a produção de alimentos para a cidade ou, ainda, mantidas pelos produtores e comerciantes para o lazer. Há também alguns projetos de reforma agrária criados nos anos 1990. 
operações burocráticas e financeiras que demandam a circulação por agências bancárias, cooperativas, cartórios e Sindicato Rural.

$\mathrm{O}$ percurso entre a cidade e as fazendas é transposto frequentemente pelos produtores, por seus funcionários, assim como por prestadores de assistência técnica e por vendedores de insumos agrícolas. $\mathrm{O}$ movimento nas estradas é mais intenso no período da colheita, considerado o mais atribulado nas fazendas. Esse processo de colheita, muitas vezes, encontra-se encadeado ao plantio do milho que ocupa boa parte das terras durante a entressafra da soja: o chamado milho "safrinha". Soja e milho são cultivos principais, mas coexistem com áreas de sorgo, milheto, arroz, feijão e algodão.

A planura da região e a sucessão de lavouras compóem uma paisagem monótona com poucas referências espaciais. A mata persiste nas margens dos rios e em manchas que intercalam as áreas exploradas, correspondendo às áreas de reserva das propriedades determinada por lei federal. Dependendo do período, percorrendo as estradas, pode-se observar as máquinas agrícolas em operação. Após a colheita, as terras que antes estavam tomadas pelas plantas alinhadas adquirem um aspecto desértico, cobertas pela palhada seca. As poucas indicaçóes de caminho que ocorrem resumem-se às placas mostrando nomes de fazendas, sendo bastante comum que fossem com sobrenomes de família.

Quase não se avista habitaçóes, a não ser as estruturas metálicas dos armazéns salientes na paisagem. Algumas capelas rurais pontuam um zoneamento por comunidades ${ }^{11}$ cotidianamente utilizado como referências territoriais pelos habitantes desses municípios. Diz-se que uma fazenda pertence a uma comunidade. As comunidades, portanto, são lugares que nucleiam a sociabilidade nessas áreas em que predominam as fazendas, estabelecendo, assim, um sentimento de pertença, demarcando uma certa abrangência territorial. Morar na fazenda corresponde a morar na comunidade.

As comunidades são frequentadas pela população rural, entre funcionários de fazenda e proprietários, em função de missas, jogos de futebol e de bocha. É preciso notar que esse público é formado predominantemente pela

II As categorias nativas (entendidas como termos especialmente relevantes para a atribuição de significado aos processos aqui descritos) estarão indicadas em itálico, assim como a ocorrência de estrangeirismos. Outras expressões locais estarão entre aspas. 
população rural de origem sulista. Os trabalhadores chamados maranhenses, numerosos nas fazendas, são raramente encontrados nas comunidades. Esses espaços merecem atenção especial por serem organizaçóes que remetem a formas de sociabilidade características das áreas coloniais do Sul. (SEYFERTH, 1990).

A maioria das famílias de produtores que acompanhamos eram de origem italiana e tinham como hábito frequentar festas católicas chamadas festas de comunidade, momentos de reunião extremamente eloquentes de um ethos característico dos colonos. Essas festas dominicais são homenagens aos santos padroeiros das capelas rurais e sáo frequentadas não somente pelos católicos, mas também pelas famílias de colonos protestantes. Participando dessas festas, pude constatar que ali estavam também em jogo relaçóes comerciais.

Cada comunidade promove ano após ano uma festa que atrai tanto a população rural quanto a urbana. Iniciam com uma missa; depois, há um almoço, leiláo de bolos e baile. Paralelamente, ocorrem torneios de futebol e de bocha. Faltando um mês para a festa, é possível observar na cidade cartazes fixados em lojas, escritórios, cooperativas e revendas de insumos agrícolas é muito comum que produtores morem na cidade e não nas fazendas. Um anúncio radiofônico também convida para a festa, anunciando a programação - missa, "suculento churrasco", torneio e "matinê dançante" - e os prêmios oferecidos para as equipes vencedoras do torneio de futebol.

As festas são momentos- chave para a viabilização da construção e manutenção das comunidades. A família que compóe a "diretoria" e os vizinhos solidários - incluindo os proprietários que moram na cidade - assumem tarefas, comprometendo-se com preparativos e desempenho de funçóes diversas no dia da festa, sem receber qualquer forma de pagamento. Diz-se, então, que alguém trabalha na festa. Eventualmente alguém pode ser contratado para trabalhar na festa, se a mão de obra comunitária for insuficiente, mas sempre de forma discreta, pois denota fraca coesão social.

Por ajuda, entende-se a forma de participação que não envolve empenho físico, sendo geralmente associada a contribuiçóes pecuniárias - em dinheiro ou em grãos - à doação de material de construção, de comida para ser consumida na festa e demais equipamentos úteis em uma numa comunidade. 
Ajudam aqueles que se consideram pertencentes à comunidade ou também aqueles considerados de fora, principalmente autoridades como o prefeito ou comerciantes de insumos agrícolas.

O comparecimento a uma festa também é considerado uma forma de ajuda uma vez que, para participar do almoço, é preciso pagar pela comida e bebida consumidas, o que será revertido em lucro para a comunidade. Dessa forma, todos que participam de uma festa de comunidade estáo ajudando. Considera-se, também, como ajudas o pagamento de dízimo e os valores dos leilóes de bolos.

A pista que indicou essa complexidade das negociaçóes demandadas a cada safra foi percebida quando participei da primeira festa de comunidade, precisamente observando o leiláo de bolos. No apregoar do leiloeiro, foram anunciados como autores dos lances não somente nomes de autoridades presentes, mas também de estabelecimentos voltados para o comércio de insumos agrícolas. Postos de gasolina e empresas que prestam serviço de armazenagem de grãos ("armazéns gerais”) também participavam. Aquela situação explicitava o quanto a festa, de algum modo, era um momento dos negócios.

Nota-se que é de interesse das empresas que as ajudas oferecidas sejam anunciadas, de alguma maneira na comunidade. Observa-se que os logotipos estão presentes em toldos provisórios e em aventais oferecidos aos homens que trabalham nas churrasqueiras em dia de festa. À entrada dos bailes, é característica a distribuição de canecos metálicos para consumir chope (igualmente decorados com o logotipo de empresas patrocinadoras). Essa relação em que as empresas ajudam a comunidade muito contribui para o aspecto geral dos pavilhôes das comunidades, especialmente suas paredes internas ocupadas por dezenas de anúncios publicitários pintados. $\mathrm{O}$ espaço nas paredes é oferecido às empresas em troca de ajuda. Esse uso das paredes também foi observado nos salóes paroquiais na cidade e no C.T.G. ${ }^{12}$.

É importante notar que as festas de comunidade assim como as demais festas que mobilizam as famílias dos produtores concentram-se entre os meses de maio e setembro, época que corresponde ao período seco e de relativo

12 Os "Centros de Tradição Gaúcha" são clubes cuja razão de ser é o culto ao chamado "tradicionalismo", "cultura gaúcha" ou simplesmente "tradição". 
"ócio" nas fazendas - como os próprios produtores explicaram. Nas primeiras chuvas, inicia-se o processo de plantio da soja e as festas só voltam a ser promovidas no final da colheita.

Todos os anos, os produtores precisam comprar sementes, fertilizantes e pesticidas para iniciar um novo ciclo agrícola. Como a maior parte das fazendas produz soja combinada com o milho "safrinha", é comum que sejam realizadas ao menos duas compras desse conjunto de produtos. A aquisição de maquinário não é realizada com a mesma frequência. Entre os grandes sojicultores, máquinas utilizadas há mais de cinco anos foram consideradas obsoletas. Cada produtor costuma ser cliente de vários vendedores.

O processo de aquisição de insumos se estende ao longo do ciclo agrícola, mas não somente em função da operaçáo de custeio e pagamento na safra, três meses depois de entregues os insumos na fazenda. Os dados mostram que a efetuação desses negócios depende de contextos de sociabilidade em que sáo firmados os compromissos informais ou um tipo de "amizade" em terreno de interesse econômico. As estratégias adotadas ao longo desse processo tendem a extrapolar aspectos estritamente técnicos (econômicos, agronômicos ou jurídicos) abrangendo questóes relativas à moralidade ou às reputaçóes construídas localmente. ${ }^{13}$

Explorando situações cotidianas e através de entrevistas com funcionários das revendas e com produtores-clientes foi possível captar a importância do mapeamento prévio dos nomes. As condições através das quais essas transaçóes vão se desdobrando dependem da credibilidade dos nomes envolvidos. $\mathrm{O}$ financiamento é a forma mais recorrente de pagamento. $\mathrm{O}$ vendedor precisa da garantia de que receberá o pagamento, assim como o produtor precisa da garantia de que o produto será entregue em sua fazenda na data acordada. Os dados permitem afirmar que a forma de garantia preferencial para ambas as partes são aquelas de ordem pessoal: o nome ou a reputação construída no âmbito daquela comunidade local. A concretizaçáo de uma venda envolve variados contextos de sociabilidade que permitem a emergência mútua dos

13 No âmbito do mesmo projeto "Sociedade e Economia do Agronegócio", as pesquisas de COMERFORD (20 I4) na região do Alto Paranaiba. Minas Gerais e WESZ JUNIOR(20 I4), no Sudeste do Mato Grosso, também exploraram a moralidade presente nas interações envolvendo produtores, comerciantes de insumos e técnicos agrícolas. 
nomes envolvidos na transação. Em outras palavras: relaçóes, por assim dizer, não-econômicas são imprescindíveis para conferir liquidez a esse mercado, viabilizando a concretização desses negócios e permitindo a sucessão de safras.

\section{Reconhecimento mútuo do nome}

Muitos dos vendedores de insumos e técnicos agrícolas atuantes na área são oriundos das mesmas regióes do Sul de onde vieram seus clientes-produtores. Alguns são filhos de pequenos sojicultores e assentados ou, ainda, conformam uma segunda leva de migrantes que náo tiveram acesso à terra; geralmente não têm mais de 40 anos - são mais jovens que a geraçáo de "pioneiros" entre 50 e 60 anos. Conheci, também, alguns casos de vendedores não sulistas oriundos de outras áreas do Centro - Oeste.

As revendas de fertilizantes e venenos são construçóes térreas em que estão instalados escritórios para seus funcionários e área de recepção. Elas podem incluir, também, uma área para estoque de produtos - o que confere um odor característico a esses lugares. As revendas de máquinas exibem seus produtos na área externa ou no interior do salão.

A decoração desses ambientes mostrou-se sóbria. As revendas geralmente possuem uma sala de recepçáo, de dimensóes variadas, em que são dispostos conjuntos de estofados e mesas baixas onde os visitantes encontram algumas revistas especializadas e panfletos de publicidade de insumos. Alguns cartazes publicitários nas paredes mostrando plantaçóes, máquinas e agricultores. Era comum que esses ambientes fossem ornados com espigas de milho ou ramos de soja, sorgo, milheto, etc.

Nos sábados, os clientes eram convidados para tomar café da manhã na revenda, quando confraternizavam com os vendedores. Os encontros entre vendedores e clientes estáo permeados por julgamentos morais e por troca de informaçóes que devem proporcionar o mapeamento mútuo das reputaçóes em jogo. A seguinte fala do gerente ${ }^{14}$ de uma revenda permite notar sobre em que circunstâncias essas reputaçóes devem ser levadas em conta:

14 As transcrições foram feitas de modo a preservar o tom coloquial 
Gerente: - Isso aí quando eu cheguei no primeiro dia também eu não significava nada. Quem é o Edson ${ }^{15}$ ? Ninguém. Mas tá começando. A partir de um determinado momento, você passa a ser respeitado como profissional competente, como uma pessoa idônea, como uma pessoa boa de negócio, como uma pessoa que não explora ninguém.

L. A.: - Como é essa relação de confiança? Como sabe que uma pessoa é idônea?

Gerente: - É simples. A gente conhece. O cara tem um histórico na região. Histórico de pagar sempre [...] Por exemplo: tem cara que liga aqui e fala: "Edson é o seguinte: eu preciso que você leve 100 litros de tal coisa pra fazenda ou entregue pra quem vai passar aí e pegar. Ele ligou, eu fiz o pedido por telefone, quem veio aqui só assinou a retirada. Eu sei que ele é uma pessoa honesta. A gente entrega, depois eu levo a duplicada e ele assina. Depois ele vai pagar. Geralmente se ele for a prazo safra, a gente leva a duplicada pra ele assinar. Ou ele, passando aqui, a gente entrega documento pra assinar. E tem cara que chega aqui e fala: "te dou hipoteca de primeiro grau". Você fala: "não... Vou ver se dá”. Então essa é a relação de confiança: tem gente que não dá garantia e você sabe que recebe e tem gente que por maior a garantia, você não vai vender. Então, essa é a relação de confiança, é o nome da pessoa. É a marca. O nome da pessoa é o que ele tem de melhor. Esse cara aqui comprou dez anos e paga conta. Esse aqui comprou 10 anos e 10 anos deu problema. E na crise, quem não paga são sempre os mesmos. E têm casos específicos: o cara ficou cinco anos negociando com você certinho, teve um ano que ele teve problema, você precisa entender a situação dele: parcelar, negociar. Então tem "ene" situações. Mas, isso aí não está em manual não. Isso tá na cabeça de quem faz [...] Tem que conhecer a região. Por isso que é muito difícil. Muitas empresas que vieram de fora sem relação com o local e abriram aqui e fecharam. Tem grandes empresas que eram do estado [do Mato Grosso], mas que não tinham uma relação direta com a comunidade que fecharam.

Esse trecho revela como garantias formais são consideradas ineficientes, visto que é primordial que o produtor com o qual se negocia tenha um nome, uma espécie de persona moral que inspira confiança. Nas palavras do gerente, ter um bom nome significa o reconhecimento como "pessoa idônea" (bom pagador, confiável), como "alguém que não explora ninguém” (pessoa justa), como sujeito "bom de negócio". Todas essas qualidades apenas podem emergir em um contexto em que as partes compartilham uma perspectiva moral. O reconhecimento de um bom nome está associado a um histórico construído ao longo de uma vida financeira. Por histórico, entende-se como uma fonte de informaçóes, atualizada cotidianamente, que permite hierarquizar nomes. Nas falas dos vendedores, o termo ocorreu no mesmo sentido, mas também em referência a um banco de dados mantido pelas revendas que registra as

15 Os nomes são fictícios. 
atividades de seus produtores. E esse registro vai sendo passado para os vendedores novatos a fim de orientá-los na disputa por clientes, permitindo que se esquivem dos mau pagadores e deem preferência àqueles produtores bem reputados ou que possuem crédito $^{16}$.

\section{Entre papelada e palavra}

Os produtores demonstraram preferência em morar na cidade, independentemente do tamanho de suas terras, e manter uma casa na fazenda. Essa escolha tende a ser justificada, por eles mesmos, em funçáo da facilidade de acesso serviços relativos a educação e saúde, por exemplo (demandas dos mais jovens e dos mais velhos das famílias). Os proprietários que habitam as fazendas são geralmente aqueles que não possuem funcionários: pequenos sojicultores, criadores de porcos e, menos frequentemente, de gado bovino.

Como mencionado no início desse artigo, a produçáo nas fazendas dependem de uma série de serviços que os produtores encontram na cidade. Operações bancárias e serviços de cartório são demandas corriqueiras. As fazendas de maior porte possuem uma espécie de extensão na cidade: os "escritórios de fazenda". Assim, os vendedores costumam frequentar os escritórios de fazenda e receber produtores na revenda.

Os "escritórios de fazenda", encontrados nos prédios da área central da cidade, podem ser encarados como materializaçóes de uma forma de organização da produção agrícola considerada "moderna". Os agricultores costumam justificar o estabelecimento desses escritórios mencionando a "papelada" produzida ao longo das safras em função do planejamento das técnicas agronômicas e das incontáveis operações bancárias, cartoriais, notas fiscais, etc. Interessante notar que essa percepção da burocratização da agricultura convive com a atribuição de valor ao compromisso pela palavra.

16 A noção de crédito que norteia essa análise vai ao encontro da proposta de Fontaine (2008) em tomar como objetos a confiança e o crédito para restituir as relações humanas à economia: em que a confiança torna as trocas possiveis - por serem previsiveis - e o crédito inscreve as relações no tempo e na relação diferenciada, irrigando, dessa forma, toda a sociedade. As relações de crédito não são somente econômicas e sociais, mas também de valores acessiveis através da descrição das modalidades concretas dessas interações. 
A fala de outro gerente de revenda, oriundo de Campo Grande/MS, estabeleceu uma relação entre a palavra e a simplicidade ${ }^{17}$ atribuída à origem "tradicional" nas áreas coloniais sulistas:

\section{L.A.: - O que você tava falando de simplicidade [dos produtores]?}

Vendedor: - Aqui as pessoas são simples, não tem maldade ainda. Elas confiam muito no que as pessoas falam. Ainda são daquele tempo em que o que você falou, vale. Isso a gente percebe... Que tem vários agricultores que você começa a negociar e, ao longo do período, você percebe isso. Você tem que tomar cuidado com o que você fala. Se falou, pra eles está escrito. É aquilo que eu disse: os agricultores vem de uma descendência de alemães, italianos, aqueles caras sérios, que foram criados dentro na roça. Eles não tiveram tempo de ir pra uma faculdade, de se formar e tal. Eles se formaram na faculdade da vida. No dia a dia deles, de repente, aqueles caras que chegaram com um pedaço de área e hoje tem áreas grandes, são caras considerados hoje muito ricos. Então isso é uma cultura que eu acho interessante. E hoje passa por uma transformação entre essa cultura do pai e a cultura do filho. Hoje a agricultura começa a incorporar tecnologia, exatamente nesse processo de transição. Onde o filho tá saindo da faculdade, está se instalando dentro da fazenda e tá com a mente aberta pra tecnologias do agronegócio. E aí pega o pai que construiu os impérios da vida aí... E e passando esse bastão pra frente (...) Hoje, os negócios são "tudo preto no branco". Gravado, escrito e registrado. Antigamente, se eu te conhecia, pelo fato de você ser filha do teu pai que era uma pessoa honesta, você tinha crédito igual. Hoje, não existe isso, nem na sociedade, nem em lugar nenhum. As coisas estão mudando. Aqui em Sorriso, apesar... Ainda existe isso. As pessoas te conhecem: "'Ah, mas é o Fagundes da Agromáquinas! Pode ir, que nós conhecemos a Agromáquinas. Nós conhecemos o Fagundes". Credibilidade ainda é um ponto fundamental aqui.

Mesmo havendo ascendido socialmente, certos produtores mantinham a "simplicidade" característica de um camponês. O narrador, no entanto, acusa uma mudança nesses hábitos, percebida no modo de negociar dos filhos: "mais abertos à tecnologia" e menos suscetíveis à influência de relaçóes pessoais; seus negócios tenderiam a assumir um caráter mais "profissional". Seus pais ainda guiariam suas decisôes comerciais por relaçóes pessoais, rechaçando tratar com pessoas que não fossem conhecidas. Nesse sentido, estariam mais "fechados" em relação a seus filhos.

A forma de negociar mais "tradicional" descrita pelo gerente mostra como essas transaçóes comerciais não são encaradas como trocas entre indivíduos:

17 A "simplicidade" como valor também aparece no artigo de Comerford (2014). 
sempre está em jogo uma chancela fornecida pela família, mesmo quando se fala uma "empresa", já que geralmente são "empresas familiares". A composição dessas sociedades familiares comumente náo extrapola o limite do núcleo familiar formado por pais, filhos e cunhados, não obstante, notamos a existência de sociedades que incluem primos. As mulheres da família tendem a ser nominalmente excluídas das sociedades, cedendo seus direitos aos esposos. Isso não significa que elas não influenciem decisóes - inclusive é frequente encontrá-las trabalhando nos escritórios de fazenda.

Ao mesmo tempo que a proximidade com os clientes permite alimentar seus históricos, também deve alicerçar a relação de confiança para atuar nesse ramo de vendas. A força desse compromisso moral é capaz de eclipsar os cálculos mais racionais, como afirmou um grande produtor: "tem gente que faz negócio porque é amigo e se dá mal”.

\section{Rotinas profissionais: construindo "intimidade" e lealdades}

Boa parte das horas de trabalho dos vendedores são despendidas nas estradas, em visitas às fazendas, circulando em veículos com os logotipos das empresas. $\mathrm{O}$ contato visual com as lavouras já permite aos olhos mais treinados perceber se as lavouras estáo "bonitas" ou se o produtor está enfrentamento alguma empestação mais grave.

A fazenda foi considerada pelos vendedores como um bom lugar para realizar a primeira visita visando ao relacionamento. Se acaso o vendedor encontrar somente funcionários na propriedade, provavelmente deixará um recado e cartão de visitas, talvez um boné decorado com os símbolos da revenda ou do fabricante de insumos.

Se a relaçáo tiver continuidade, ele encontrará o proprietário numa dessas visitas. É prudente que já tenha levantado informaçóes sobre a distribuição de funçóes na sociedade familiar, ao menos a fim de saber quem é "o cabeça” em matéria de negócios ou o encarregado da relação com os vendedores. Poderia encontrá-lo, talvez em um final de tarde, formando uma roda de chimarráo reunindo outros homens da família ou, ainda, as mulheres também estivessem ali - situação mais provável no caso daqueles produtores que moram na 
fazenda. A etiqueta determina que não há impedimentos maiores em incluir estranhos em uma roda de chimarrão - como pesquisadoras forasteiras podem constatar em campo.

Se estiverem nessa roda apenas os funcionários da fazenda, o convite para que o vendedor tome chimarráo continua sendo muito provável. As conversas com funcionários, entretanto, poderão assumir um tom mais "interessado". Nessa ocasiáo, o vendedor poderá obter informaçóes estratégicas para a venda em horizonte. Alguns vendedores explicaram que a explicitação do interesse comercial em conversas com os agricultores ou mesmo o manuseio de uma "pastinha" contendo os formulários de pedidos logo na primeira visita pode comprometer o prosseguimento da negociação na medida em que enfraquece o tom de amizade que essas relaçóes devem adquirir.

As técnicas utilizadas pelos vendedores também são conhecidas pelos agricultores. A precisão dos dados obtidos inclusive impóe restriçóes ao negociar, uma vez que impede que, no jogo de barganha, os agricultores possam valer-se do segredo para obter melhores condiçôes, pois sabem que suas atividades são acompanhadas de perto:

Produtor: - As empresas é o seguinte: as empresas tem um gerente que... Fica três, quatro, cinco anos. Aí eles mudam. Aí vem outro que não conhece a gente, não conhece... Mas aquele que sai já dá o currículo de cada um: ó tenho o produtor tal... Eles tem no computador deles lá, lista lá. E, eles sabem a vida de cada um.

L.A.: - Ah, é?

Mulher do produtor: - A vida financeira. Quem que não sabe de quem?

Produtor: - A vida financeira. As empresas sabem mais do que os próprios produtores.

L.A.: - Eles são bem informados.

Produtor: - São. Eles tem equipe, eles tem... Hoje então com computador que se vê a lavoura lá dentro do escritório. Então, eles já sabem como é que tá. E eles têm o pessoal deles, agrônomos que percorrem as lavouras, e vê como é que tá a lavoura de um, do outro. Mesmo quem não financia com eles, eles já sabem. Então eles tem informação. (...) Por isso que eu falo: às vezes, chega numa empresa, não adianta mentir. Eles sabem mais do que a gente. Se chega lá e diz: - não, eu não tenho nada (...), - não, o senhor tem lavoura em tal lugar. Tá aqui:, o senhor produz tanto. Lá os cara falam pra eles. Eles não perguntam: quando você colheu? Eles não perguntam. Essa pesquisa eles vão fazendo lá. Eles passam na lavoura e perguntam pro meu gerente: - que média tá colhendo? - 60 sacos por hectare.

Tudo bem!. Eles vão embora. O cara plantou 1.000 hectares, colheu 60 mil sacas. 
As etapas possíveis dessa negociação ou do relacionamento consistem numa série de práticas que tem como objetivo transpor os limites da mera impessoalidade, de modo que o vendedor seja aceito no restrito grupo com o qual um determinado agricultor negocia. Nesse sentido, o agricultor está "fechado" em um círculo de confiança, em uma relação que demanda determinado tempo para ser construída.

Os relatos dos vendedores revelam que o primeiro momento do negócio não deve envolver a menção a valores, até que o cliente tome a iniciativa. Logo, terá início uma sequência de visitas e encontros em que as partes $b a-$ tem papo e tomam chimarrão. Nessas ocasióes, como forma de demonstrar comprometimento, os vendedores podem tratar de não impor o horário de expediente ao tempo da amizade.

O pagamento pelos insumos geralmente ocorre alguns meses depois da formalização do pedido e da entrega na fazenda. Os vendedores levam em consideração o risco de não receber o pagamento. A inevitável oscilação das cotaçóes pode alterar os valores negociados em relação ao que foi estabelecido no momento do contrato, o que pode causar conflito entre as partes e o rompimento da aliança comercial ou da amizade. Os vendedores relataram que, no caso de uma alta nas cotaçóes, existem produtores que se recusam a pagar. $\mathrm{O}$ empenho em construir o relacionamento acaba, também, cercando os produtores de modo a imprimir-lhes algum senso de obrigaçáo que garanta o pagamento.

As falas dos vendedores apontaram alguns aspectos da sociabilidade que denotam a existência de uma relação de "confiança" ou um certo grau de "intimidade" característica. Participar das mesmas festas ou, entáo, o acesso ao âmbito doméstico - , sobretudo às mulheres da família, especialmente as esposas dos produtores - , foram consideradas situaçóes associadas à amizade.

Dentre as situaçóes usadas pelos vendedores para ilustrar como eles vivenciam essa relação de amizade com seus clientes vale destacar que, uma imagem recorrente frequentemente usada para denotar "intimidade" remete àqueles momentos em que o produtor está trabalhando duro sobre a máquina e convida o vendedor para acompanhá-lo na cabine: 
Praticamente eu ia uma vez por semana na fazenda dele, tipo rotina. Hoje já faz três meses que eu não vou na fazenda dele e ele me cobra: -“"por que você não vem mais aqui?"” Ele quer que você esteja lá não só porque você faz negócio, mas por uma consideração de amizade. Que nível de amizade, eu não sei dizer, mas é consideração pela pessoa. E aí depende de cada um. Tem produtor, por exemplo, que não tem nada para fazer e vem na revenda conversar com você. Passar o tempo, tomar chimarrão. Nesse período que é mais tranqüilo. Daqui a pouco, daqui a quinze dias começa a colheita de milho, eles somem tudo. Só acha na lavoura. Mas você tem - "relacionamentos e relacionamentos". Por exemplo: a maioria dos meus clientes, tenho a liberdade de chegar na fazenda dele, e ele tá trabalhando e eu entrar na [máquina] colhedeira e ficar conversando com ele e ele colhendo. Já se você é um novato, se você fizer isso talvez ele: - “Peraí, passa outro dia que hoje eu tô colhendo”'. E já como você é conhecido, é amigo e tem contato, já tem uma história, ele não vai falar: -“’passa outro dia”. Vai falar: -“'Entra aí, eu não vou parar de colher. Mas entra aí, vamos conversar!"”. (gerente de uma revenda especializada em insumos para milho).

Notamos que a proximidade social que demanda uma amizade também está relacionada aos momentos de lazer. As pescarias, por exemplo, reunindo os homens indicam que ali já existe alguma "intimidade", na medida em que permitem transpor a trivial sede da fazenda para conhecer os recantos de pesca da propriedade. Os rios da região são pontuados por estaçóes de acampamento e pesca que eles chamam de "pesqueiro" ou simplesmente ceva - nome também dado à soja, mergulhada nas curvas dos rios, como isca.

A evolução no sentido de uma amizade "verdadeira" ou de uma relação que permite sobrepujar o frio "interesse comercial” deverá também reunir as famílias. A venda de uma máquina colheitadeira também pode servir como ensejo para que o vendedor e cliente reúnam-se para assar carne e beber chope no final de semana, na companhia de suas famílias para comemorar o fechamento de um negócio. Essas festas provavelmente ocorrerão no final da colheita, quando também finalmente é realizado o pagamento em grãos. As revendas inclusive mantém um fundo para promover essas comemoraçóes.

Após a colheita da soja, inicia a plantação do milho e começa a temporada de festas, entre março e outubro. Se o vendedor de máquinas - ou de outros insumos - quiser voltar a negociar com o produtor, buscará comparecer às festas de igreja ou de outras agremiaçóes frequentadas por seus clientes como os "clubes de serviço" (Rotary Club e Lions Club), os clubes gaúchos "C.T.G.s" e eventos da Maçonaria. 
Nas festas de comunidade, observamos que os vendedores que dela participavam, não costumavam pagar seus gastos com bebida e comida no dia da festa. O valor geralmente era cobrado dias depois, quando membros da comissão responsável pela festa iam à cidade para acertar as contas: esse intervalo de tempo também pode ser interpretado como parte dessa etiqueta que busca imprimir a essas relaçóes um caráter desinteressado, de amizade.

Percebemos que o estabelecimento das relaçóes de confiança se efetiva por meio da articulação de manifestaçóes mais corriqueiras e superficiais das partes - como as trocas de tíquetes de cerveja nas festas - e de situaçóes mais dramáticas que podem contribuir para estabelecer lealdades, por assim dizer, mais instantâneas.

As doenças da lavoura, por exemplo, tornam os produtores vulneráveis de modo que a resoluçáo do problema atribui notável prestígio ao seu responsável. É importante notar que a geração de pioneiros geralmente não domina as técnicas de cultivo sofisticadas que aplicam em suas lavouras. Como forma de suprir essa necessidade da fazenda, é comum que seus filhos sejam enviados para estudar em escolas de Agronomia no Sul.

Como os vendedores de insumos, via de regra, são técnicos agrônomos, eles mesmos, muitas vezes, encarregam-se de aconselhar os produtores, não somente orientando na aplicação dos produtos que eles mesmos oferecem, mas também na solução de problemas mais sérios, como uma grave empestação na lavoura. Um pequeno produtor comparou a atuação dos vendedores à dos médicos.

A aceitação, por parte do produtor, da receita sugerida pelo técnico-vendedor denota uma relação de confiança, mas também cria uma situação que pode colocar essa mesma relaçáo em risco.

Outro episódio que ilustra as manifestaçóes mais dramáticas de lealdade diz respeito à participação de vendedores em protestos políticos dos produtores. Em 2004, os produtores locais organizaram o bloqueio de estradas como forma de pressionar o governo federal pela renegociação de dívidas. Esses bloqueios duraram ao menos uma semana e vendedores de insumos relataram que estiveram "acampados na BR" junto aos produtores. 
Finalmente, situaçóes excepcionais, assim como contatos mais triviais entre vendedores e produtores, revelaram como o mercado de insumos agrícolas, marcado pela financeirização e pela sofisticação tecnológica, opera através de garantias pessoais. Preços, condiçóes dos contratos e garantias patrimoniais são, sem dúvida, aspectos fundamentais para a definição dessas transaçóes, no entanto, a falta de um lastro moral deve comprometer duramente sua eficácia. A construção de relaçóes de confiança, entendidas aqui como um jogo social das reputaçóes, mesclando cálculos aritméticos e moralidade, parece ser o fator essencial para a liquidez desse mercado. Os dados levam a crer que as trocas comerciais só são possíveis entre pessoas que compartilham um mesmo horizonte moral, vivenciado e atualizado na vida comunitária - seja na intimidade da casa ou da comunidade, no escritório da fazenda, no banco ou sobre a máquina colheitadeira.

\section{Referências}

ALMEIDA, L. Gaúchos, festas e negócios: o agronegócio da soja no Meio-Norte matogrossensemato. 2013. 1981 f. Tese (Doutorado em Antropologia Cultural) Programa de Pós-Graduaçáo em Antropologia Cultural, PPGSA, Universidade Federal do Rio de Janeiro, Rio de Janeiro, 2013.

BAILEY, F. Gift and poison. In: Gift and Poison. Oxford: Basil Blackwell, 1971. p. $1-25$

COMERFORD, J. Produzindo moralidades: dilemas, polêmicas e narrativas em terras do "agronegócio". In: CARDOSO DE OLIVEIRA, R; WERNECK, A. (org.),(Org.). Pensando bem: estudos de sociologia e antropologia da moral. Rio de Janeiro: Casa da Palavra, 2014. p. 156-181.

DELGADO, G. Expansão e modernização do setor agropecuário no pós-guerra: um estudo da reflexáo agrária. Estudos Avançados, São Paulo, v. 15, São Paulo: v. 15, n. 43, set./dez. 2001.

DESCONSI, C. A marcha dos pequenos proprietários rurais: trajetórias de migrantes do Sul para o Mato Grosso. Rio de Janeiro: E-papers, 2011.

FERNANDEZ, A. J. Do Cerrado à Amazônia: as estruturas sociais da economia da soja em Mato Grosso. 2007. 228 f. Tese (Doutorado em Desenvolvimento Rural) - Programa de Pós-Graduação em Ciências, PGDR, Universidade Federal do Rio Grande do Sul, Porto Alegre, 2007. 
FONTAINE, L. L'économie morale. Pauvreté, crédit et confiance dans l'Europe préindustrielle. Paris: Gallimard, 2008.

HEREDIA, B.; PALMEIRA, M.; LEITE, S. P. Sociedade e economia do "agronegócio"” no Brasil. Revista Brasileira de Ciências Sociais (RBCS), v. 25, n. 74, p. 159-176, 2010. LEITE, S.; WESZ JUNIOR, V. J. Estado, políticas públicas e agronegócio no Brasil. Revista Pós Ciências Sociais, v. 11, n. 22, p. 83-108, jul/dez. 2014.

MORENO, G. Terra e poder em Mato Grosso: política e mecanismo de burla (1892 a 1992). Cuiabá/MT: Entrelinhas e EDUFMT, 2007.

SEYFERTH, G. Imigração e Cultura no Brasil. Brasília: Editora Universidade de Brasília, 1990.

SORJ, B. Estado e classes sociais na agricultura brasileira. Rio de Janeiro: Zahar, 1980.

TAVARES DOS SANTOS, J. V. Matuchos: exclusão e luta do sul para a Amazônia. Petrópolis: Vozes, 1993.

WESZ JUNIOR, V. J. O mercado da soja e as relaçóes de troca entre produtores rurais e empresas no Sudeste do Mato Grosso (Brasil). 2014. 220 f. Tese (Doutorado em Ciências Sociais), - Programa de Pós-Graduação em Ciências SociaisCPDA, Universidade Federal Rural do Rio de Janeiro, Rio de Janeiro, 2014. 


\section{In festive occasions, offices and tractor cabins: observations about the comercial transactions envolving inputs in soybean agribusiness}

\section{Abstract}

The commercial dimension of agricultural production mobilizes expressively soybean producers do Mid - northern Mato Grosso, precisely the micro-region of Alto Teles Pires. They report that the marketing of the product, since the implementation of crops in the late 1970s to the 1990s, took place without being required to have in order to precise calculations to achieve good business results. The tendency to reduce the profit margin and the sophistication of production techniques require producers to carry out complex and detailed calculations. This article seeks to explore a small part of this universe of agricultural business focusing on commercial transactions between sellers of agricultural inputs and soybean producers. The proposal is to show how the complex calculations of the agricultural commodities market involve aspects that go beyond the "economic" as the reputations of the parties. We will see that these changes can be understood by exploring the bridges between rationality "economic" and moral judgments.

Keywords: Agribusiness. Market. Moralities.

Recebido em: 16/02/2016 Aceito em: 10/12/2016 